\title{
The influence of organisational stressors on the well-being and performance of operational police members
}

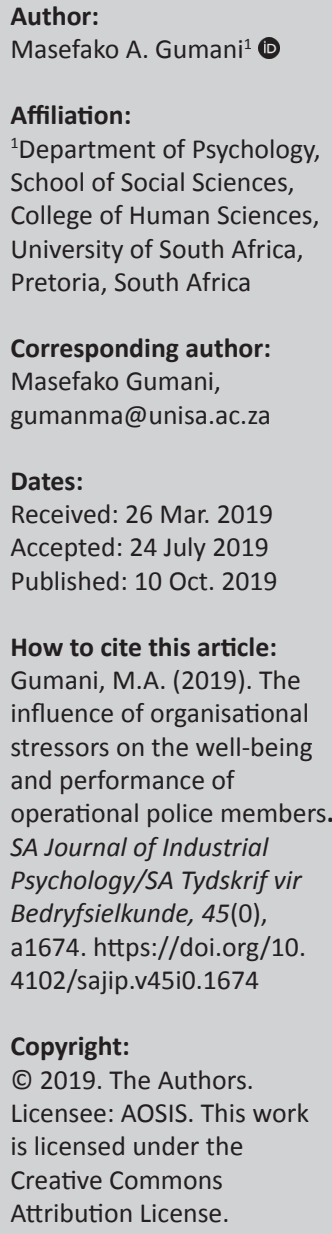

Orientation: Studies on the influence of organisational stressors on the well-being and performance of operational members of the South African Police Service in the visible policing and detective service programmes in rural areas, like the Vhembe district, Limpopo province, South Africa, have not been conducted yet.

Research purpose: The aim of this study was to explore and interpret operational members' experiences of organisational stressors, which influence their well-being and performance when attending to critical incidents of rape, domestic violence, murder and road accidents, in the Vhembe district, Limpopo province.

Motivation for the study: The study proposes ways of dealing with organisational stressors that influence the well-being and performance of operational members when performing their tasks.

Research approach/design and method: An interpretative phenomenological research design was used and 17 South African Police Service participants were selected through purposive sampling. Unstructured face-to-face interviews, diary entries and telephonic interviews were conducted and field notes were used to collect the data, which were analysed using interpretative phenomenological analysis guidelines.

Main findings: The results highlight internal, external, task-related and individual organisational stressors among operational members of the South African Police Service that led to psychological distress, including negative perceptions of self and work, job dissatisfaction, considerations of resignation, increased training needs and strained working relationships.

Practical/managerial implications: A need for a systems perspective on problem-solving, with top-bottom and bottom-up approaches, is proposed to manage organisational stressors among operational members of the South African Police Service in the Vhembe district.

Contribution/value-add: The study contributes towards the contextual understanding and management of organisational stressors in rural operational policing.

Keywords: Critical Incidents; Operational Work; Organisational Stressors; SAPS; Industrial Psychology; Rural Area; Victim Empowerment.

\section{Introduction}

Research on the influence of organisational stressors (unfavourable work conditions and tasks, including human resource management, record-keeping and bureaucratic procedures) is still relevant today (Acquadro Maran, Zedda, \& Variety, 2018; Redelinghuys, Rothmann, \& Botha, 2019) in police organisations (Shane, 2010). These stressors include work procedures and processes in the public sector, like policing, which play a major role in ensuring efficient service delivery in relation to available resources (Nzewi, 2013). The stressors not only influence work performance and wellbeing but also impact employee attrition (employees leaving an organisation), which calls for continued research on organisational stressors that lead to these challenges (Redelinghuys et al., 2019). The patterns of resignation among the South African Police Service (SAPS) members because of organisational stressors in the past 3 years are as follows, namely, 1889 in 2016/2017 and 2039 in $2017 / 2018$, which suggests that there is an increase in the trend. This is the reason why improving the operational work environment has been set as a priority in the SAPS (SAPS, 2017/2018).

South African Police Service studies on the influence of organisational stressors were mostly conducted among randomly selected police members (Louw \& Viviers, 2010; Madu \& Poodhun, 2006; Meyer, Rothmann, \& Pienaar, 2003; Mostert, Cronje, \& Pienaar, 2006; Pienaar \& Rothmann, 2003, 2006; Storm \& Rothmann, 2003; Wiese, Rothmann, \& Storm, 2003) and did not focus on 
members performing operational work (work that involves exposure to victims' critical incidents) (Rees \& Smith, 2008). The organisational stressors have been indicated to impact the work efficiency of operational police members in the metropolitan areas (Kgalema, 2002) and in some rural parts of the country (Steyn, 2009). Based on findings in Italy, Acquadro Maran et al. (2018) recommended a comparison of organisational stressors (organisational demands that are primarily and directly embedded in the work environment and affect an employee's performance) (Hanton, Fletcher, \& Coughlan, 2005) and operational stressors (demands of working and making decisions during critical incidents) (Rees \& Smith, 2008), and their effects on the physical and psychological health of patrol police members. Although the current study does not compare the two types of stressors, limited literature on the influence of organisational stressors on operational SAPS members necessitated this study.

South African studies that have suggested a link between the two stressors are the following, namely, Kgalema (2002), who conducted a study in the Metro policing areas of eThekwini, Johannesburg, Cape Town, Tshwane and Ekurhuleni; Steyn (2009), who conducted a study on SAPS members in a rural area but only focused on the types and frequency of exposure to traumatic events; and Van Lelyveld (2008), who conducted a quantitative study that only determined how demographic factors and workload impacted the existence of Vicarious Traumatisation (VT). VT is a type of operational stress signified by a change in helping practitioners' inner experience because of indirect and empathetic exposure to clients' critical incidents (Ludick, Alexander, \& Carmichael, 2007). Because possible links have been found among operational police members in these South African samples, this study aimed to explore the influence of organisational stressors among operational SAPS members in the visible policing and detective service programmes who are managing the policing needs of victims of rape, Domestic Violence (DV), murder and road accidents in the Vhembe district.

Bakker and Demerouti (2018) show that the well-being and performance of employees are affected by several organisational stressors, but empirical evidence on the dynamic impacts of organisational, leadership and team stressors on individual employees is still scarce. Such studies on police stations in rural areas are deemed limited based on study findings in Scotland (Smith, 2010). Yet findings in Australia show that such studies highlight the effectiveness of policing in relation to the characteristics of the rural communities being served (Jobes, 2003). Different reactions to organisational stressors among police members in rural and urban areas have also been found in South Korea (Lim \& Kim, 2015). These are the reasons why the current study's focus is on the influence of organisational stressors on operational members of the SAPS in a rural district.

It is stipulated in the foreword by the Minister of Police, Mr Henry Cele, in the SAPS Annual Performance Plan $(2018 / 2019)$ that plans were made to attend to organisational dynamics that negatively impact the roles and performance of operational police members. The plans, among others, include ensuring operational training of the police and providing resources that meet international standards to guarantee effective policing. This shows the need for further research to inform the supportive plans of the SAPS.

This study sought to qualitatively explore and interpret organisational stressors that are likely to occur among operational SAPS members in the Vhembe district and the consequent difficulties. The research question was the following, namely, 'how do SAPS members who do operational work in the Vhembe district experience the influence of organisational stressors in their work environments?' The Vhembe district was chosen for the following reasons.

The SAPS (2018) reported the following patterns of serious crimes in the country between 01 April 2017 and 31 March 2018: contact crimes (murder; sexual offences; attempted murder; assault with intent for grievous bodily harm; common assault; common robbery; robbery aggravated, including carjacking, residential and non-residential robbery) - 36.2\% (601 366), contact-related crimes - 6.9\% (115361), other serious crimes - 26.3\% (438113), and propertyrelated crimes $-30.5 \%$ (507 975). Motives for murders resulting from criminal behaviour were gang-related, taxi-related, and political-related. They were also associated with illicit mining, farm murders, mob justice, and murdering of police members.

In Vhembe district, the following increases in contact crimes were noted between 2011 and 2012, namely, murder cases increased from 18 to 24 , attempted murder from 53 to 58 , sexual crimes from 321 to 391, assault with intent to inflict grievous bodily harm from 700 to 794 , common assault from 580 to 829 , common robbery from 239 to 287 and robbery with aggravating circumstances from 133 to 215 (SAPS Crime Statistics, 2012). Current statistics show that the Thohoyandou police station in the Thulamela municipality, Vhembe district, was rated the fourth worst police station in the Limpopo province in 2018 because of the large number of reported crimes, amounting to 11 124. These included contact crimes like murder, attempted murder, sexual offences, assault with intent to inflict grievous bodily harm, common assault, common robbery and robbery with aggravating circumstances (Crime Statistics South Africa, 2018). The following statistical patterns of contact and other serious crimes between 2016 and 2018 in the Vhembe municipalities of Mutale, Thohoyandou, Tshaulu and Vuwani were found, namely, murder (71-81), sexual offences (279-357), attempted murder (87-111), assault with intent to inflict grievous bodily harm (731-936), common assault (695-912), driving under the influence of alcohol and drugs (421-506) and sexual offences detected as a result of police action (4-65) (Crime Statistics South Africa, 2019). These statistical patterns suggest that the occurrence of these crimes have remained relatively high over the years.

In addition, there is no research conducted on the link between organisational stressors and operational work in this district, yet literature emphasises studying this phenomenon in various rural areas in South Africa (Steyn, 
2009; Van Lelyveld, 2008) and in other countries (Acquadro Maran et al., 2018; Jobes, 2003; Lim \& Kim, 2015; Smith, 2010). The study findings should contribute to the body of knowledge in industrial psychology on current organisational stressors that influence operational SAPS members' wellbeing and performance. It should also inform the proposals to be drafted on the transformation of the SAPS operational police service (SAPS, 2018/2019).

\section{Links between organisational and operational stress}

Acquadro Maran et al. (2018) note that there is still much controversy within police research regarding the causes of the two forms of work-related stress, namely, organisational stress, which is experiences of psychological and physical strain resulting from a mismatch between the demands and pressures of work and an employee's coping capacity (Babatunde, 2013), and operational stress such as experiences of trauma emanating from routine and vicarious exposure to critical or traumatic incidents of victims (Rees \& Smith, 2008). Various reports on the impact of organisational and operational stressors have been outlined. Some studies have reported that organisational stressors are more stressful, while others have cited that operational stressors are more stressful (Acquadro Maran et al., 2018; Lim \& Kim, 2015). Kohan and Mazmanian (2003) have also found different perceptions of organisational and operational work based on the types of duties of police members.

Still other findings suggest the likelihood of convergence between the impacts of these two categories of stressors. A link was found between perceived increase in the organisational stressors of operational patrol police members and diminished well-being and performance (Shane, 2010). Acquadro Maran et al. (2018) have also found that operational or outdoor patrol members are more prone to suffer distress because of organisational and operational stressors than intra-departmental or indoor patrol members. However, organisational stressors were reported to be more problematic than operational stressors, leading to behavioural disengagement. Lim and Kim (2015) stated that organisational stress weakens the ability of field police members to perform their operational tasks. Kgalema (2002) confirmed the causes of organisational stress among operational police members as organisational stressors, such as the lack of or insufficient training, lack of follow-up on victims and repeated exposure to traumatising situations. The impact of organisational stressors is said to be 'relentless and inescapable', and has to be a priority for employee assistance programmes for operational police members (Shane, 2010, p. 185).

Conducive organisational conditions thus mediate the impact of critical incidents on operational police members (Maguen et al., 2009). Consequently, daily routine work challenges and operational work are regarded as crucial determinants of organisational stress and health among police members (Berg, Hem, Lau, \& Ekeberg, 2006). Conducive organisational conditions have also been reported to moderate the experience of VT (Bober \& Regehr, 2006), which has also been reported among South African police members (Kgalema, 2002), including operational SAPS members (Van Lelyveld, 2008). These include supervision and peer consultation, critical incident debriefing, professional training and self-assessment, juggling duties at work and a reasonable workload. This explains the reason why the fit between an individual and the work environment determines an employee's degree of job satisfaction - perceptions of an employee's wants being met at work (Redelinghuys et al., 2019). For this reason, SabinFarrell and Turpin (2003) show that the conditions under which helping practitioners - including police members who play a helping role within community policing (SAPS Annual Report, 2010/11) - work can determine the development of VT. Such conditions encompass the physical setting, the types of colleagues they work with, the caseload, supervision and services available to clients that are assisted, social and professional climates, and the way that financial issues such as staff remuneration are handled in an organisation. Pearlman and Sakvitne (1995) add organisational stressors such as a lack of time off work, an environment of disrespect and a lack of confidentiality and boundaries as contributory factors to this phenomenon. This further shows the impact of organisational stressors among helping practitioners, like operational police members.

\section{Sources and outcomes of police organisational stress}

Babatunde (2013) provides the following categories as general sources of organisational stress, namely, intrinsic job roles (work overload, time pressures, lack of job control and poor working conditions), role in an organisation (role stress, role conflict, role ambiguity and level of responsibility), career development (lack of job security, over-promotion, under-promotion and career stagnation), work relationships (workplace bullying, superior/ subordinate face-offs, dark leadership and discrimination) and organisational climate or structure (formalisation, management style and decision-making participation).

Organisational stress among the police members is caused by the conditions, policies and procedures under which police members work (Burke \& Paton, 2006, p. 1). These include job content or inherent job demands and job context or context job demands. The former are demands that are inherent in the job role, which include work schedules such as workload, repetitive tasks, long working hours, time pressure, exposure to demanding crime and traumatic scenes, and court work. These demands require physical and psychological effort and thus affect the well-being of police members and hamper their job performance. The job context or context job demands include organisational characteristics and the behaviour of those working in the context, which produce stress like imbalance between effort and rewards, relationship with and support from supervisors and coworkers, workplace discrimination, bureaucratic processes, poor leadership and insufficient staff, and administrative duties (Babatunde, 2013; Lim \& Kim, 2015; Patterson, 2001b; Violanti et al., 2017). 
The following types of police organisational stressors have been identified over the years, namely,

1. internal stressful events like policies, administration and availability of resources

2. task-related stressful events such as workload and shifts, and relationships with superiors

3. external stressful events like the justice system, public's perceptions of police work and sociopolitical changes and

4. individual stressful events, for example, life characteristics that impact police members' work (Acquadro Maran et al., 2018; Patterson, 2001b).

Lim and Kim (2015) concluded that police work comprises dynamic stressors. These are work-related factors that are changeable - for example, bureaucracy level in a police organisation, police relationships with communities, police skills, as well as job description and autonomy. The police work also encompasses static stressors. These are workrelated factors that remain invariable, for example, gender, years of police service, location of police station and supervisory position.

The following organisational stressors cause harm to police members, namely,

1. general poor well-being like exhaustion or burnout, digestive disorders, cardiovascular disease and psychological distress (depression and anxiety)

2. negative job-related experiences like job dissatisfaction, rumination, helplessness, employee resignation, early retirement and absenteeism

3. performance-related problems like low morale, poor performance, being late for work, career uncertainty, lack of commitment to work and work-life conflict

4. psychosocial problems, for instance, divorce and suicide and

5. behavioural problems like hyper-aggression, excessive use of force, substance and alcohol abuse, and a threat to safety (Acquadro Maran et al., 2018; Babatunde, 2013; Lim \& Kim, 2015; Redelinghuys et al., 2019).

\section{Theories of organisational fit, motivation, job satisfaction, well-being and performance}

The following theories shed light on the understanding of organisational stressors and their impact on job satisfaction as well as the well-being and performance of employees. The current study could add to the theories by highlighting these from operational SAPS members' experiences.

Firstly, the person-environment fit theory, which was developed by theorists such as Robert D. Caplan and Amy L. Kristof-Brown, among others, and explains the correlation between a person's characteristics and job constructs. It indicates that positive correlations between these two lead to positive outcomes, while the opposite leads to negative outcomes like maladjustment and poor work performance. The following models have been developed which highlight the likely components of fit in the work environments of operational police members, namely, person-job fit (a match between an individual's ability and job demands or tasks), person-organisation fit (link between the values of an employee and the organisation), person-group fit (compatibility between an individual and his or her work groups), person-supervisor fit (the match between the attitudes of supervisors and their subordinates), needssupplies fit (correlation between an employee's needs and organisational supplies, rewards) and demands-abilities fit (a match between job demands and an employee's knowledge and abilities) (Klaic, Burtscher, \& Jonas, 2018).

An association between the constructs of person-environment fit and job satisfaction is also shown. Job satisfaction reveals employees' perception of the extent to which their wants are met at a workplace as well as the amount of congruence between their perceptions and values. How they perceive their wants to be met in their organisations determines how satisfied they become with their jobs. This also influences how they perceive themselves to fit within their organisations and jobs (Redelinghuys et al., 2019).

The person-environment fit theory highlights the significance of a match between a police member's attributes, knowledge or abilities, values and needs, and the characteristics of the police organisation or unit and relationships to ensure good role performance and job satisfaction.

Secondly, the multiple levels in job demands-resources theory propose buffers for organisational stress. It helps to understand how operational police members' well-being and performance could be enhanced amidst organisational stressors. The following are considered.

Job demands (work tasks requiring effort and thus cause strain and negative behaviours) may influence employees, but the employees can also influence those demands through job crafting (making changes to work tasks and relationships). Also increasing organisational resources to achieve work goals is important as it increases employees' motivation and work engagement (a positive state of mind emanating from a work environment that stimulates involvement, vigour, dedication and absorption) in the midst of high job demands. In addition, employees' wellbeing, behaviour and performance are influenced by various organisational stressors at multiple levels within the work environment, including organisational initiatives and leaders and teams' behaviours. Therefore, proper management of workplace resources and relationships may lead to work engagement, job satisfaction, wellbeing and performance. (Bakker \& Demerouti, 2018).

Similarly, Meyer, Gagne and Parfyonova's (2010) evidencebased engagement framework draws from Edward L. Deci and Richard M. Ryan's self-determination theory of motivation as well as John Meyer and Natalie Allen's three-component model of commitment to give a sense of hope amidst organisational stressors. The framework shows that work engagement, in the forms of intrinsic and extrinsic motivation and commitment, 
can be harnessed among employees when supportive organisational environments, suitable working climates and congruent organisation-employee values are created. The outcomes include a sense of autonomy, employee need satisfaction, behavioural engagement, increased performance, decreased employee resignation rates and employee wellbeing. Therefore, both the multiple levels in job demandsresources theory and the evidence-based engagement framework show how the SAPS operational environment and resources can be enhanced to achieve these outcomes.

\section{Research design \\ Research approach and strategy}

A qualitative, Interpretative Phenomenological Analysis (IPA) was used to explore and interpret operational SAPS members' experiential meanings of being-in-the-world of handling the critical incidents of victims amidst organisational stressors, as well as their experiences of well-being and performance. Double hermeneutics was applied whereby a narrative account of the participants' experiences was written to reflect both their own interpretation of their experiences and my interpretation of their communicated experiences. This led to a shared interpretation of participants' experiences (Pietkiewicz \& Smith, 2014).

\section{Research setting}

The Vhembe district is situated far north of Limpopo province and has four municipalities, namely, Musina, Makhado, Thulamela and Mutale. Nemasisi (2018) confirms the statistics provided above on the occurrence of violent crimes in this district. This puts pressure on the police members because they have to manage many critical incidents. For instance, the Thohoyandou Victim Empowerment Programme (TVEP) was established in the district in 2002 in the form of the Thohoyandou Victim Empowerment Trust and later was formally registered as the TVEP. The programme was formed based on the efforts of the Thohoyandou Community Policing Forum and the SAPS with the aim of curbing rife cases of abuse and supporting and empowering victims (Carty, 2010/2012). For this reason, policing appears to be visible (visible policing) in this district; hence, police stations are located at the entry points of major areas and villages. Based on these efforts and literature that emphasises studying the link between facing critical incidents (operational work) and organisational stressors in various rural areas in the country (Steyn, 2009; Van Lelyveld, 2008), as well as the lack of research conducted in this rural district, the district was seen as a viable option for this study. The district has a population of 1232218 and is mainly a rural district. However, infrastructural developments are taking place. Tshivenda is the most spoken language, followed by Xitsonga and others (Department of Cooperative Governance and Traditional Affairs, 2011).

\section{Field entry and establishing researcher role}

Police station commissioners assisted with access to willing potential participants.

\section{Selection of participants}

Purposive sampling, which is a sampling technique used to intentionally select participants who possess specific characteristics, including experience regarding the phenomenon under study, and can share knowledge about it (Franchuck, 2004), was used to select the study participants. They had to work in the family violence, child protection and sexual offences (FCS); DV; detective; social crime prevention (SCP); and field training police units, which handled incidents of rape, DV, murder and road accidents in the Thulamela and Mutale municipalities. The sample comprised 17 participants who were self-reported to experience VT reactions (see Table 1). The sample size of 17 was decided based on the IPA's recommended small sample sizes for indepth engagement with individual participants' data (Pietkiewicz \& Smith, 2014) as well as for reaching data saturation.

\section{Data collection methods}

Unstructured interviews were conducted and the main interview question was as follows, namely, 'could you please tell me how you experience your work conditions when helping victims of critical incidents in the communities that you serve?' Follow-up questions were asked. Among the Tshivenda-speaking participants, the interviews were conducted in their language in order to ensure that they were comfortable to express themselves and to share as much information as possible. However, one Xitsonga-speaking participant indicated the ability to express himself in English and was comfortable to do so. Nevertheless, it was taken into

TABLE 1: Profile of the study participants.

\begin{tabular}{ll}
\hline Variables & Characteristics \\
\hline Municipalities & Thulamela and Mutale \\
Police units & 7 \\
FCS/DV & 6 \\
Detective & 3 \\
SCP & 1 \\
Field training & \\
Police ranks & 1 \\
Superintendent & 1 \\
Captain & 11 \\
Inspector & 1 \\
Sergeant & 3 \\
Constable & 7 months to 24 years \\
Operational work experience & Grade 10 - university degree \\
Level of education & \\
Gender & 13 \\
Male & 4 \\
Female & 14 \\
Marital status & 3 \\
Married & $27-55$ years \\
Single & \\
Age range & 16 \\
Language or cultural group & \\
Tshivenda & \\
Xitsonga & \\
\hline FCS - Family violence, child protection and sexual offences; DV - Domestic violence; SCP - \\
Social crime prevention. & \\
&
\end{tabular}


consideration that interviewing the Xitsonga-speaking participant in English could have restricted him from fully and clearly articulating his experience of the phenomenon under study. In addition, while careful translation of data from Tshivenda to English by a translator who is fluent in both languages was observed, the process could have led to some loss of meaning. Each interview lasted for about $1 \mathrm{~h}$. Data were also collected through diaries and telephonic follow-ups to corroborate the interview data, thus ensuring triangulation and credibility of findings (Graneheim \& Lundman, 2004). Both the face-to-face and telephonic interviews were conducted in pre-arranged private rooms (the police members' offices, station commissioners' offices and rooms where victims of DV were attended to) depending on where the members felt comfortable and could not be overheard by others.

\section{Data recording}

The interviews were voice recorded, verbatim transcription was made and field notes were taken.

\section{Strategies to ensure data quality and integrity}

In addition to triangulation, two experienced researchers verified the authenticity of the themes developed. The telephonic interviews were used for member checking. Indepth descriptions of the methodology were also provided. Thus, the credibility, confirmability, dependability and transferability of the findings were ensured (Graneheim \& Lundman, 2004).

Individual police members signed consent forms after being informed of the purpose, risks involved and the right to withdraw from the study. Anonymity was ensured by using participant numbers. Voice-recorded data were deleted after transcription to ensure confidentiality. Potential emotional harm was prevented by not forcing participants to reveal issues that they did not want to discuss. The participants did not want the free consultation that was arranged with a clinical psychologist outside the SAPS. Consequently, the only indirect benefit of the participants was an opportunity to share their experiences on the topic under study to inform the development of assistance programmes for operational police members, specifically in the Vhembe district.

\section{Data analysis}

The following IPA guidelines from Pietkiewicz and Smith (2014) were applied, namely, individual transcripts were read several times for data familiarity (i.e. content, language usage, context, relationships and time). Interpretation notes and analytical memos were written and converted into emerging themes for conceptual understanding. Similar incidents in a transcript were compared. The themes were clustered based on similarities, and a table with superordinate and subordinate themes was created. The whole process was applied to all the transcripts, and new themes were noted with similarities and differences from individual experiences. A master table of themes was created and a narrative account of the participants' experiences was written and contextualised in current literature. A qualitative, narrative reporting style was followed to present and discuss the findings of the study.

\section{Results}

Operational police members in this study indicated that they experience organisational stressors at different levels at the workplace, which result in psychological distress, including negative perceptions of self and work, job dissatisfaction, considerations of resignation, increased training needs and strained working relationships. The themes and subthemes that emerged are presented in Table 2.

\section{Case exposure}

\section{Quantity and frequency of case exposure}

The police members complained that they are being overloaded with traumatic cases. For example,

TABLE 2: Influences of organisational stressors among operational police members in the Vhembe district.

\begin{tabular}{|c|c|c|c|c|c|}
\hline \multirow{2}{*}{$\begin{array}{l}\begin{array}{l}\text { Organisational stressors } \\
\text { superordinate themes }\end{array} \\
\text { Case exposure }\end{array}$} & \multirow{2}{*}{$\begin{array}{l}\text { Organisational stressors } \\
\text { subordinate themes } \\
\text { Quantity and frequency of case } \\
\text { exposure }\end{array}$} & \multicolumn{4}{|c|}{ Reported organisational stress reactions } \\
\hline & & Intruding thoughts & - & - & - \\
\hline & Timing of case exposure & Emotional despair & Fear & Feeling overwhelmed & - \\
\hline & Type of case exposure & Perceived work difficulty & $\begin{array}{l}\text { Emotional } \\
\text { despair }\end{array}$ & - & - \\
\hline \multirow[t]{8}{*}{ Police member support } & Variable victim support & $\begin{array}{l}\text { Perceived victim secondary } \\
\text { victimisation }\end{array}$ & Being discouraged & - & - \\
\hline & $\begin{array}{l}\text { Unnecessary bureaucratic } \\
\text { processes }\end{array}$ & $\begin{array}{l}\text { Perceived delayed } \\
\text { help for victims }\end{array}$ & Perceived work difficulty & - & - \\
\hline & Divergent debriefing services & $\begin{array}{l}\text { Lack of debriefing accepted as } \\
\text { part of police work }\end{array}$ & Thoughts of resignation & $\begin{array}{l}\text { Perceived low status of } \\
\text { police work }\end{array}$ & - \\
\hline & Unmet training needs & Feeling of inadequacy & $\begin{array}{l}\text { A need for more skills } \\
\text { training }\end{array}$ & - & - \\
\hline & Provision of incentives & Dissatisfaction with work & $\begin{array}{l}\text { Perceived low status of } \\
\text { police work }\end{array}$ & Discouragement & Frustration \\
\hline & Member favouritism & Distrust for superiors & $\begin{array}{l}\text { Distrust for fellow-police } \\
\text { members }\end{array}$ & $\begin{array}{l}\text { Member factions within } \\
\text { police units }\end{array}$ & Feeling restricted \\
\hline & Lack of peer support & Perceived work difficulty & $\begin{array}{l}\text { Perceived consideration of } \\
\text { perpetrators over victims }\end{array}$ & - & - \\
\hline & $\begin{array}{l}\text { Fragmentation in law } \\
\text { enforcement }\end{array}$ & $\begin{array}{l}\text { Perceived consideration of } \\
\text { perpetrators over victims }\end{array}$ & Pain perceived police failure & $\begin{array}{l}\text { Frustration } \\
\text { self-doubt }\end{array}$ & Helplessness \\
\hline
\end{tabular}


superintendents who are in a senior position and are responsible for allocating cases may allocate too many cases to themselves and end up being overwhelmed. The most common reasons for this were the shortage of staff and reluctance of police members to join the FCS police unit because of the nature of cases dealt with. The result may be intruding thoughts about such cases, which can linger in the mind for months or even years:

$[R]$ equesting for more personnel to be transferred to my unit ... none of those members applied to be in the unit ... I used to take each and every case ... It means each case makes me to recall a lot ... This is more than a year. All those things do not get out of my mind. (Participant 1, Male, FCS)

One police member shared contrasting reports about the quantity and frequency of exposure to cases, defined by time intervals. While he reported that voluminous exposure to similar cases (quantity) over time served as a solution to getting used to the operational work and thus gaining experience in handling the cases, the frequency of exposure to the cases in a day also led to intrusions:

The only way of forgetting about a particular case is when you have to come across many other cases after this one ... there are days on which I work on a lot of cases ... three or four cases, then I will be thinking about them the whole day. (Participant 13, Male, Social crime prevention)

\section{Timing of case exposure}

Exposure to traumatic cases has various time dimensions, which may influence police members differently in the forms of emotional despair, fear and feeling overwhelmed. These dimensions include exposure to traumatic cases when entering the police service - thus not having the required experience - and first time exposure to specific types of cases, such as gang rape and murder. This may be exacerbated by exposure to victims of specific age groups, children and the elderly in this case. It is argued that experience in handling specific cases helps with understanding the distress associated with such cases, and how to handle the cases:

This affected me a lot because it was my first case ... a case of a 7-year old ... one of the cases that I worked on when I started working. I had not yet worked on other cases to have knowledge of other causes of the rape of young children, and why they were affecting me in that manner. (Participant 2, Female, FCS)

During our first years of working ... the impact was there as we were affected. When alone I would be afraid ... (Participant 3, Male, Detective)

During my first year of working I attended a case on culpable homicide ... an accident involving a dead person. This was the first traumatic case that I worked on. I found it too big for me and felt that I could not handle it. (Participant 5, Male, Social crime prevention)

\section{Type of case exposure}

Attending to a post-mortem, especially that of a ritual murder, for the first time and being actively involved in assisting doctors to conduct post-mortems on dead bodies may be difficult to accept and thus emotionally disturbing:
... [A]t first it is hard ... the first case whose post-mortem I attended was of a body that ... most of the parts were removed and it was hard ... it is hard at first to accept it ... You are the one who must direct him, that 'I want this'. (Participant 6)

\section{Police member support}

\section{Variable victim support}

The police members explained that they provide a supportive role to community members during critical incidents, thus serving as helping practitioners in the SAPS. However, they reported that they faced an ambivalent situation of helping victims of trauma without the necessary facilities and supplies, thus wondering how they were supposed to do their work. When the victim empowerment service was required, there were no facilities or resources (shelters or places of safety, counselling rooms, blankets, vehicles, computers, telephones to call the victims and transport for police members after attending to the victims late at night), and scant availability of other personnel to provide supportive services. Additionally, the working hours of other helping practitioners (psychological counsellors, social workers and so forth) did not match those of the police members because police work was reported to be a 24-h service. This thwarted police members' referral role to those other helping practitioners. This was interpreted as a form of secondary victimisation of victims, and thus discouraging:

... [W] do not have a place here to shelter her ... victims have to sit on a bench the whole night and this is not comfortable ... A victim is treated like the accused here ... we do not have blankets, a place to sleep and it is very cold ... as police members we indicate that there is nothing that we can do to help ... We do not have people who provide counselling services ... a victim empowerment organisation does not exist. We only have a temporary thing ... a desk for victim empowerment ... does not even operate for 24 hours the same way as police members do ... when I work until late I do not get transport to take me home. (Participant 7, Male, Detective)

... I do not have a phone in my office ... to phone someone who needs my assistance ... I cannot just leave them unattended. I do not have a computer either in my office ... (Participant 8, Male, Detective)

Some police members, nevertheless, indicated that they had the required facilities, resources and personnel at their police stations. These include trauma centres attached to police stations, witness protection programmes and day-to-day supplies for doing the work properly. Referral to various other professionals such as social workers, magistrates, doctors and the National Prosecuting Authority (NPA) was easier because of the availability of necessary facilities and personnel. An ideal victim empowerment programme was portrayed. The active involvement of station commissioners in the arrangement of the required resources was highlighted:

The victim will be taken to a doctor ... form part of the evidence that will be used in court ... If we do not have a car in our branch then we ask for a car from the station commissioner ... (Participant 5, Male, Social crime prevention)

... [S]peak to my superior and explain that the victim is not safe ... apply to the NPA for a witness protection programme 
... who will inform me of the date on which to bring the victim ... we refer children to social workers in the Department of Social Welfare and Development ... (Participant 9, Female, FCS)

... [T] here is a lot of support. You can never attend to a crime scene without the necessary resources. This helps in protecting our health. (Participant 10, Male, Domestic violence)

The trauma centre is right here ... police members take them [victims] to sleep there for their safety ... They will be counselled ... 'I am taking you to the magistrate's office to have a protection

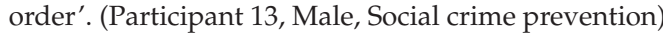

\section{Unnecessary bureaucratic processes}

Where referral was possible, especially to clinical psychologists, such referral was not as smooth as expected because of unnecessary bureaucratic processes, which made the task of victim assistance difficult and delayed the help:

We also refer them to [clinical] psychologists so that we can discuss our cases with the prosecutor. If a psychologist does not want me to make a referral on my own then I request the public prosecutor to write a letter of referral to the psychologist. (Participant 2, Female, FCS)

\section{Divergent debriefing services}

Although the need for debriefing after exposure to traumatic cases by professionals, like psychologists, was expressed, a lack of such debriefing ended up being accepted as part of police work. Thoughts of resigning from work still remained. The lack of this support resulted in one police member equating policing to the job for the uneducated:

I could appreciate the support from our superiors ... being assisted by those who ... trained to provide counselling services because the victim's experience also affects me. It is often taken for granted that we are not affected by these situations ... we are now used to the setting ... concluding that perhaps this is how we are supposed to live ... to put our experiences into perspective and help us to cope ... I feel like resigning is better. I think about this all the time ... What can we do? This is the job for the uneducated. (Participant 7, Male, Detective)

However, police members from different police stations had different experiences of this form of support. Some members indicated that they received the required debriefing by psychologists, social workers and pastors:

... [W] have supporting units ... psychologists and social workers ... to provide counselling and debriefing. (Participant 4, Female, Field Training)

... [A]lso pastors who come to the station to encourage us in our work. (Participant 5, Male, Social prevention)

... [C]onsult with the EAS [Employee Assistance Services] personnel who will tell you how you can handle the situation ... spiritual and social work services. (Participant 9, Female, FCS)

The SAPS arranges people who can counsel us when we have these constant thoughts about cases until they stop ... (Participant 11, Male, Social crime prevention)

\section{Unmet training needs}

The police members emphasised that they are often the first ones to arrive at crime scenes and are in constant interaction with victims of trauma who experience suicide ideation and physical injuries. Such situations require them to offer support to victims, which may be beyond their job description and training. While referral to more experienced professionals like counsellors, firefighters and Emergency Medical Services (EMS) personnel is a requirement within their job description, some of the victims' conditions are so dire that immediate attention is required; hence, police members may try to assist the victims. Leaving a victim in the experienced state while waiting for other professionals to arrive was interpreted as inhumane. 'Trying to help', which was echoed by several police members as a way of containing the victims' situations and emotions, was regarded as an option. Pressure from onlookers during road accidents was also a reality as they expected the police members to 'do something'. 'Devising ways of helping' per case was said to be customary for them. A shortage of the professionals and long distances were cited as causes of the problem, and police members therefore expressed the need for extra skills in basic counselling, especially for special populations, first aid services and spiritual support.

... [S]he was crying ... needed more help from me than I could offer as a police member ... thinks of committing suicide ... I try my level best ... I do not want to leave the victim ... (Participant 2, Female, FCS)

I must wait for the fire fighters and the EMS personnel to arrive ... to assist as he is trapped under the car ... community members shouting at you as they think that police members are able to do any type of work ... our training should be expanded ... on first aid services ... domestic violence and ... how a person is counselled. (Participant 3, Male, Detective)

... [Y]ou must start by assisting the person to face the situation before you can refer them ... calm them down ... take up the role of a pastor ... saying a prayer ... This line of work requires training in ... counselling skills ... social work skills ... to give advices and devise solutions for various situations ... have advanced knowledge about victims of trauma and what psychologists do ... Sometimes victims come across urgent situations, which cannot wait ... You cannot leave the victim in an office unattended ... it takes time for a young child to talk about such things ... start by telling jokes and play ... when the child is free to speak, you start writing ... (Participant 9, Female, FCS)

You must try ... You must just remove her from the anger that you are observing in her ... use tactics depending on the nature of the situation. (Participant 13, Male, Social crime prevention)

The members who have received some level of training in these areas emphasised the value of workshops on human rights and basic counselling:

... I no longer have a problem ... Courses help us a lot ... taught about such severe scenes ... through simulated scenes ... (Participant 5, Male, Social crime prevention)

... [W] have been workshopped about human rights ... we are able to sit down with a person and counsel them ... (Participant 13, Male, Social crime prevention)

\section{Perceived fair pay and career development opportunities}

A lack of sufficient financial benefits was interpreted as a lack of support at work and a cause of dissatisfaction with the work. One member even likened police work to selling tomatoes because work had to be done but there were no matching financial benefits (salary and compensation) across ranks. Attending to critical incidents without any prospects 
of promotion to a higher rank was also reported to be discouraging. Even more frustrating was the lack of transparency on criteria for promotion, as the members were often not promoted regardless of experience and qualifications. Only their financial circumstances compelled them to continue with policing:

We do not really have support here ... the work that I do can be likened to selling tomatoes ... Our superiors ... get better benefits while the juniors do not receive much. We are not remunerated for working overtime $\ldots$ being told to pursue a suspect who has stolen millions of rands from a bank while I am only earning a few thousand rands! ... [T] he money for compensation in case I am killed while on duty is very little ... We are forced to do this work because we are poor ... It is not rewarding... a percentage increment in salary does not make a difference to me. (Participant 7, Male, Detective)

$[T]$ here is no promotion here at work regardless of studying or showing competence in one's work. We do not know which criteria are followed to promote people in this place. ((Participant 8, Male, Detective)

\section{Member favouritism}

Member favouritism was also experienced, as some unit commanders favoured certain members over others. The result was that it led to the distrust of team members and superiors and created factions among members within the units:

$[H]$ aving a commander who favours a particular group ... you forget a small thing, which may be important in the evidence ... you may not be treated well ... if the same mistake is done by someone else then it may not be a big issue. This does not make a person feel free. (Participant 5, Male, Social crime prevention)

I am led by somebody who was lied to about me and believed what he was told without first ascertaining this with me. Leadership is lacking ... (Participant 12, Male, Detective)

\section{Lack of peer support}

Both low- and high-ranking members mentioned that at times they had to work with pessimistic, uncooperative and lazy colleagues. Some hid case and court information from them. Ill-treatment by colleagues in the form of speaking malicious words about them to superiors, and even to community members, concerning the members' incompetency in handling cases was also reported. This signified not caring about victims and made their operational work difficult to do.

... [W] hen they have to check the DNA and involve psychologists ... will say, 'Oh! It is a lot of work'. They are not there to do that type of a thing ... 'We will all get our salaries even if we did not do the work ...' (Participant 1, Male, FCS)

$[W]$ hat makes work difficult is working with people who are negative in their thinking ... not cooperative and are always complaining about work and lack of resources ... (Participant 8 , Male, Detective)

I complained of lack of cooperation among us as police members ... no communication ... working in this manner was not satisfactory ... (Participant 9, Female, FCS)
$[W]$ hen working on domestic problems ... a member ... will go home and tell the people involved in the case that the member working on the case has not handled it well ... (Participant 14, Female, Domestic violence)

... I can request one of them to attend to a case and only find that he has not attended to it thoroughly ... (Participant 15, Male, Detective)

\section{Fragmentation in law enforcement}

Most members showed that while there were case investigations that led to the perpetrators' incarceration, corruption and unfavourable court decisions were also common. These were in the forms of case dockets disappearing, distorted evidence, underserved bail, lenient sentences, disposal of serious cases of rape and murder, and premature release of perpetrators from correctional centres, and without rehabilitation. This was done without consideration of the incriminating evidence presented and the impact of the crimes on victims, even in crimes perpetrated by senior police members. This was interpreted as consideration of perpetrators' rights over those of victims. Experiences of pain, frustration, helplessness, perceived failure and self-doubt were reported:

[A] slim chance to win this type of case in court ... the type of frustration I have ... you may have overwhelming evidence against a perpetrator ... but the court says 'No, ... this person has the right to be released'. (Participant 1, Male, FCS)

I defend a bail but the magistrate grants it ... it is not handled according to the report presented ... the accused is given a sentence of 10, 15 or 5 years ... come back not rehabilitated ... and commit the same offences. (Participant 2, Female, FCS)

The state strips us of power ... the accused has more rights than the victim ... (Participant 7, Male, Detective)

I looked for the docket but could not find it ... I discovered that the docket was with the public prosecutor ... I asked the PP [public prosecutor] for a warrant of arrest but he refused ... This appears as though I am not doing my work ... (Participant 9, Female, FCS)

$[A]$ criminal who ... fabricates stories ... in order to find a way out of the crime ... this is painful ... (Participant 10, Male, Domestic violence)

[A] lawyer ... asking you questions to misrepresent your responses ... It makes you feel like you have not done your job properly ... (Participant 11, Male, Social crime prevention)

\section{Ethical considerations}

Permission and ethical clearance were obtained from the Provincial Commissioner of the South African Police Service and the Department of Psychology at the University of South Africa to conduct this study.

\section{Discussion}

\section{Outline of the results, practical implications and recommendations}

The nature of the findings gathered requires that they should be discussed concurrently with practical implications and viable recommendations (see Table 3). 
TABLE 3: Recommendations for a systems approach to handling organisational stressors in a police operational setting in the Vhembe district.

\begin{tabular}{|c|c|c|}
\hline Reported organisational stressors & A systems perspective to problem-solving & Problem-solving approaches \\
\hline $\begin{array}{l}\text { Unsupportive police leadership and } \\
\text { unit teams }\end{array}$ & $\begin{array}{l}\text { Strengthened police leadership and team work } \\
\text { Department of Police } \\
\text { - Increasing resources and policing budget } \\
\text { - Improving work conditions } \\
\text { - Employing more operational police members } \\
\text { Unit commanders and individual operational police members } \\
\text { - Tailor-made operational case allocations } \\
\text { - Considering police individual personality traits, individual preferences and level of operational work } \\
\text { experience during case allocation } \\
\text { - Creating work breaks } \\
\text { Industrial and clinical psychologists } \\
\text { - Assessments and recommendations for member operational work suitability (considering police } \\
\text { individual personality traits, individual preferences and the level of operational work experience) } \\
\text { - Designing operational training programmes for police members } \\
\text { Unit commander leadership training for the management of operational units } \\
\text { Unit commanders and peers } \\
\text { - Comradeship (collegial support and information sharing) }\end{array}$ & $\begin{array}{l}\text { Combined top-bottom and } \\
\text { bottom-up approaches }\end{array}$ \\
\hline $\begin{array}{l}\text { Discrepancies in victim } \\
\text { empowerment and support }\end{array}$ & $\begin{array}{l}\text { Groundwork for victim empowerment and support } \\
\text { Departments of Police/SAPS, Social Development and Health } \\
\text { - Addressing VEP inconsistencies } \\
\text { - Easy accessibility of basic psychological, social and emergency services (employment and deployment } \\
\text { of registered counsellors, social workers and EMS personnel at police stations) } \\
\text { Station commissioners } \\
\text { - Interest in developing police stations } \\
\text { - Negotiating with the government to meet station-specific VEP needs } \\
\text { Unit commanders, and industrial and clinical psychologists } \\
\text { - Entry level safe, simulated case exposures } \\
\text { - Continuous trauma management education } \\
\text { Industrial and clinical psychologists } \\
\text { - Detective entry level training through systematic desensitisation under observation } \\
\text { Registered counsellors } \\
\text { - Identification of cases that require basic emotional and situation containment (rape, domestic violence, } \\
\text { road accidents and murder, and others) and basic training } \\
\text { - Visible basic psychological services (close working relationship with operational police members at most } \\
\text { common VEP programme entry points, e.g. crime scenes and the Customer Service Centres) } \\
\text { Clinical psychologists } \\
\text { - Training in handling rape cases of minors and the elderly } \\
\text { - Improved referral system } \\
\text { Senior/experienced detectives } \\
\text { - Collegial support (accompanying junior detectives during difficult cases) } \\
\text { Researchers } \\
\text { - Studies on continuous adjustments in operational police training } \\
\text { SAPS supporting units and peers } \\
\text { - Consistent police operational debriefing services (clinical psychologists, social workers and pastors) } \\
\text { - Relevant organisational stress debriefing }\end{array}$ & $\begin{array}{l}\text { Combined top-bottom and } \\
\text { bottom-up approaches }\end{array}$ \\
\hline
\end{tabular}

SAPS, South African Police Service; EMS, emergency medical services; VEP, Victim EmpowermentProgramme.

\section{Influences of organisational stressors}

The following issues are highlighted in this study:

- The reported organisational stressors influenced the psychological well-being (personal growth, meaning, purpose and workplace relations) (Redelinghuys et al., 2019) and performance (Babatunde, 2013) of the operational police members, thus suggestive of organisational stress in the forms of negative thoughts and intrusions, emotional despair (Acquadro Maran et al., 2018), negative perceptions and acceptance, feeling demotivated (Redelinghuys et al., 2019), perceived professional incompetence (Violanti et al., 2017), need for more professional skills (Rees \& Smith, 2008) and separation from others. Reports of these negative perceptions, thoughts, affect and behaviour because of exposure to the negative organisational stressors, which are depicted in Table 2, signify a presence of unpleasant reactions to the stressors and thus dissatisfaction with their jobs (Redelinghuys et al., 2019).

- However, the stressors are not unique to the setting in the Vhembe district because they have been identified among several police and other samples of helping practitioners in South Africa and globally, and they include perceptions relating to, namely, work experience and case exposure; availability of infrastructure, resources and personnel; member support (debriefing services and peer and superior encouragement); fair pay and career development opportunities; comprehensive training; and integration of law enforcement and the judicial system (Burke \& Paton, 2006; Coetzee, 2005; Kgalema, 2002; Patterson, 2001b; Pienaar \& Rothmann, 2006; Waters \& Ussery, 2007).

- Negative implications for practice regarding a police member's satisfaction with working in an operational SAPS unit have been noted about the following: demands of victim support versus police members' resources, knowledge and abilities; attitudes and values of individual members versus those of unit commanders and team members; and the match between the members' needs and the SAPS rewards (Klaic et al., 2018).

- While the location of the police stations in a rural district cannot be changed, the identified organisational stressors can be modified (Lim \& Kim, 2015), and hence the police members' suggestions for change.

These are explicated below.

\section{Combined top-bottom and bottom-up approaches to problem-solving}

This study supports Bakker and Demerouti's (2018) theory that the operational police members' work environment has multifaceted job demands in addition to their individual needs. This requires consideration of a top-bottom and 
bottom-up systems approach to problem-solving to devise relevant interventions that will ensure police members' satisfaction with their jobs. The following were considered.

The need for a strengthened police leadership and teamwork was evident. The operational members in this study used the top-bottom approach (relying on their superiors to determine work conditions) to deal with work challenges. What happened at the organisational, leadership and team levels led to the perception of their operational work as difficult and unworthy, being hindered, and not being supported in doing their work and progressing to higher ranks. This, in turn, affected their well-being and performance. While some reported provision of support, most of them showed that they could not make changes to how they implemented work tasks and managed relationships with unit commanders and peers (Bakker \& Demerouti, 2018). One member in a very senior rank perceived the detrimental influence of allocating many cases to oneself because of a shortage of staff and lack of interest in police members to join a police unit. This means that while the bottom-up approach that police members suggested to make changes to their work environment (Bakker \& Demerouti, 2018) to solve the problem could have been adopted in this case, the problem was complicated even more. The problem implied the involvement of the state in increasing personnel. It also implied consideration of individual police members' values, interests and preferences. Therefore, the effectiveness of individual coping resources was dependent on both higher and external resources.

Perhaps the solution lies in combining the top-bottom and bottom-up approaches to problem-solving. The first step is the Department of Police's investment of more resources (Bakker \& Demerouti, 2018) and increasing the policing budget in order to improve the work conditions and personnel (top-bottom approach), especially in rural areas. The second step is to strike a balance between personal and environmental characteristics (Redelinghuys et al., 2019) whereby unit commanders could actively involve police members in tailoring their work environments (Bakker \& Demerouti, 2018) through gathering suggestions for improvement and co-planning operational work activities. The involvement of industrial and clinical psychologists in assessing the police members' suitability to assist with critical incidents and recommending training requirements (Department of Health, 2011) could also be helpful. This could deal with the ambivalences of case exposure pertaining to police members' varying experiences of quantity, frequency, timing and type of case exposure (in this district, cases of rape, DV, road accidents and murder). The following characteristics could be considered: individual personalities, individual preferences and level of operational work experience. Allowing breaks from work could also be of benefit (Salston \& Figley, 2003). In this way, police members' influence on how job goals are achieved (bottom-up approach) (Bakker \& Demerouti, 2018; Morash, Haarr, \& Kwak, 2006) could be encouraged.

Attention was also drawn to problematic leadership styles of some unit commanders regarding member favouritism, peer factions and office gossiping. This highlights the need for unit commanders to be trained by industrial and clinical psychologists in a specific leadership style in the operational setting. This could emphasise aspects such as operational office etiquette and sensitivity to individual police member needs. Unit commanders have to understand that they are leading individuals who are constantly exposed to traumatic situations, which may make them even more sensitive than the general public to suggestions of being overlooked in the workplace. Perhaps if unit commanders could instil the value of comradeship among peers (Waters \& Ussery, 2007), it could help police members to be more empathetic towards one another, considering the trauma that their work entails. They would also be more supportive and would share the required case information.

Adding to the police organisational stressors are VEP paradoxes in the Vhembe district, which still have to be dealt with by the SAPS and the Department of Social Development, which is the custodian of the VEP (Department of Social Development, 2009). Birdsall, Kirby and McManus (2017) state that while studies on victim engagement are still new, they provide valuable knowledge that could be applied in the practice of victim empowerment. This study provides some findings on organisational stressors during the police members' engagement with victims that could contribute towards this course, with implications for industrial and other psychological services. The study suggests that efficient victim empowerment and support is possible in rural areas, provided that there is preparation to ensure availability of the following VEP requirements.

Uniform victim support - Irregularities in facilities, resources, personnel and services, as well as provision of transport after working hours and police training, which affect the quality of victim support, were noted. The interest of station commissioners in developing their police stations and their active involvement in negotiating with the government for the availability of VEP requirements were emphasised as solutions by the police members. This is, therefore, recommended as a starting point to address these irregularities.

According to the SAPS Annual Report (2010/2011), the following forms of training were already in place by then, namely, entry-level training for new recruits and managers, and in handling traumatic cases; advanced training in detective, victim support, emergency care development and violence against women and children; and leadership training, including police station management. The study shows that despite these and other training considerations by the SAPS, the following knowledge and skills gaps are urgent needs in the Vhembe district:

- High levels of prior operational work experience to face grave crime scenes during the initial years of policing are required (Rees \& Smith, 2008) - continuous exposure to a safe environment of simulated cases with support from unit commanders as well as industrial and clinical 
psychologists could help in this instance with acquisition of basic experience before they are allocated real cases. Continuous education regarding trauma and its management has also proven valuable (Bell, Kulkarni, \& Dalton, 2003), because police members' level of education determines the type of coping resources they use. This is because research shows that higher levels of education correlate with the ability to regulate one's emotions and to seek social support (Patterson, 2001a).

- Experience in facing mutilated corpses and active involvement in post-mortems among detectives appears to be a requirement - training could include systematic desensitisation, still in a safe environment, under professional psychological observation at the entry level by industrial and clinical psychologists. Accompanying junior detectives by experienced detectives during difficult cases could help absorb the pressure of exposure to such scenes until the required experience has been gained.

- Basic skills related to emotional and situation containment are also necessary - this suggests identification of the nature of cases that require such skills, including rape, $\mathrm{DV}$, road accidents and murder. Offering basic training by registered counsellors in emotional and situation containment could help, as the counsellors' academic training prepares them for such a role (HPCSA, 2013).

- Knowledge and skills in handling rape cases of children and the elderly were noted. Similarly, Coetzee (2005) found that SAPS members who were investigating cases of sexual abuse needed in-depth training in interviewing children - clinical psychologists whose work involves dealing with life and developmental challenges (Department of Health, 2011) could assist with equipping the police members with such skills. Continuous adjustment in training with new organisational research findings is thus recommended to prevent the police members going beyond their job description.

Harmonious interdepartmental referrals - The need to refer victims' cases without hassles, especially to clinical psychologists, was highlighted to prevent delays in victim help. This shows the need for an improved police referral system to clinical psychologists. Visibility and easy accessibility of registered counsellors as community workers are also crucial (HPCSA, 2013). The employment and deployment of registered counsellors in police stations is important for basic psychological counselling services to be provided on a $24-\mathrm{h}$ basis to match the police members' operational work expectations as suggested by some of the police members. This also calls for a close working relationship between registered counsellors and operational police members at the most common VEP programme entry points, namely, the crime scenes and the customer service centres at police stations (points where victims receive initial help from the police) (Department of Social Development, 2009). This would accompany visible policing with visible psychological services. The counsellors' visibility in communities could also reduce the pressure on police members to handle victims' immediate psychological needs, and thus not having to go beyond their job description. The same applies to social workers and EMS personnel. This has implications for the involvement of the Departments of Police, Social Development and Health.

Consistent police debriefing services - Randomness in rendering debriefing in police stations, which undermines operational police members' psychological health needs, was also noted. Babatunde (2013) shows the importance of effective stress management interventions in ensuring employee well-being and productivity. Such interventions should also be relevant to the type of police stress in operational settings (SabinFarrell \& Turpin, 2003), in this case stress that is induced by organisational stressors. Strengthening the debriefing services by the SAPS supporting units (clinical psychologists, social workers and pastors) as suggested by the police members in this study is crucial. The recommendation for comradeship among peers would also set the stage for introducing peer debriefing, which was deemed successful among other samples (Waters \& Ussery, 2007) in order to fill the gaps in the SAPS debriefing efforts.

All these would encourage workplace flourishing - an employee's perception of fitting in well with work, thus feeling and performing well in the workplace, and enjoying job satisfaction (Redelinghuys et al., 2019) among these operational police members.

\section{Study limitations}

The study limitations include the police units, ranks and member characteristics (age, gender, cultural group and religion), which were not equally represented in the study; however, these did not impact the credibility of the study as it did not intend to achieve this goal. The participants were self-reported to be experiencing VT reactions, and thus the study was not based on professional diagnostic reports. The findings are restricted to application within the study setting. Using telephonic interviews to ensure credibility and confirmability could have yielded insincere responses. No comparisons were made between the influences of organisational and operational stressors, as well as ways of coping with the combination of the two. Future quantitative and qualitative research should attend to these factors.

\section{Conclusion}

This study makes a meaningful contribution towards the understanding that organisational stressors influence operational SAPS members' well-being and performance. This influence is multi-layered, thus requiring a systems perspective (the state, the SAPS, other government departments, including industrial psychologists and other psychology practitioners, station commissioners, unit commanders, peers and individual police members) with top-bottom and bottom-up approaches to deal with the 
organisational stressors, and to ensure effective victim empowerment and support in the Vhembe district.

\section{Acknowledgements}

I would like to thank the University of South Africa for the funding of research publication fees for this paper.

\section{Competing interests}

The author declares that they have no financial or personal relationships which may have inappropriately influenced them in writing this article.

\section{Authors' contributions}

M.A.G. (University of South Africa) is the sole researcher and author of this article.

\section{Funding information}

This study was supported by a grant from the University of Venda Research and Publications Committee for the main study from which the current one was extracted, titled: 'A grounded theory of police critical incidents impact management amongst SAPS officers in the Vhembe District, Limpopo Province.'

\section{Data availability statement}

Data sharing is not applicable to this article as no new data were created or analysed in this study.

\section{Disclaimer}

The views and opinions expressed in this article are the author's own and do not represent an official position of the University of South Africa or the University of Venda.

\section{References}

Acquadro Maran, D., Zedda, M., \& Varetto, A. (2018). Organizational and occupationa stressors, their consequences and coping strategies: A questionnaire survey
among Italian patrol police officers. International Journal of Environmental among Italian patrol police officers. International Journal of Environmental
Research and Public Health, 15(1), 166. https://doi.org/10.3390/ijerph15010166

Babatunde, A. (2013). Occupational stress: A review on conceptualisations, causes and cure. Economic Insights: Trends and Challenges, II(3), 73-80. https://doi. org/10.1002/9781118539415.wbwell019

Bakker, A.B., \& Demerouti, E. (2018). Multiple levels in job demands-resources theory: Implications for employee well-being and performance. In E. Diener S. Oishi, \& L. Tay (Eds.), Handbook of wellbeing (pp. 1-13). Salt Lake City, UT: D. Oishi, \& Lublishers.
DEF Put

Bell, H., Kulkarni, S., \& Dalton, L. (2003). Organizational prevention of vicarious trauma. Families in Society: The Journal of Contemporary Human Services, 84(4), 463-470. https://doi.org/10.1606/1044-3894.131

Berg, A.M., Hem, E., Lau, B., \& Ekeberg, O. (2006). An exploration of job stress and health in the Norwegian police service: A cross sectional study. Journal of Occupational Medicine and Toxicology, 1(26), 9. Retrieved from http://www. occup-med.com/content/1/1/26.

Birdsall, N., Kirby, S., \& McManus, M. (2017). Police-victim engagement in building a victim empowerment approach to intimate partner violence cases. Police Practice and Research, 18(1), 75-86. https://doi.org/10.1080/15614263.2016. 1230061

Bober, T., \& Regehr, C. (2006). Strategies for reducing secondary or vicarious trauma: Do they work? Brief Treatment and Crisis Intervention, 6(1), 1-9. https://doi org/10.1093/brief-treatment/mhj001

Burke, K.J., \& Paton, D. (2006). Well-being in protective services personnel: Organizational influences. Australasian Journal of Disaster and Trauma Studies, 2(1), 1-13.
Carty, C. (2010/12). Zero tolerance village alliance intervention model: Evaluation and report (Report). Thohoyandou: The Thohoyandou Victim Empowerment Programme.

Coetzee, C. (2005). An explorative study of the training needs of investigating officers interviewing young victims of sexual abuse. Unpublished master's thesis, Stellenbosch University, Stellenbosch.

Crime Statistics South Africa. (2018). Crime stats simplified. Retrieved from https:// www.crimestatssa.com/toptenbyprovince. php?ShowProvince=Limpopo

Crime Statistics South Africa. (2019). Limpopo - Crime stats simplified. Retrieved from https://www.crimestatssa.com/provinceselect.php?ShowProvince=Limpopo\#.

Department of Cooperative Governance and Traditional Affairs. (2011). Vhembe District Municipality Profile. Retrieved from www.nda.agric.az/.../profiles $\% 20$ 1011\%20vhembe\%20aug.docx.

Department of Health. (2011). Government notice: Regulations defining the scope of the profession of psychology. Retrieved from www.hpcsa.co.za/Uploads/.../ scope_of_profession_of_psychology_sept_2011.pdf

Department of Social Development. (2009). National policy guidelines for victim empowerment. Pretoria: Department of Social Development. Retrieved from https://pmg.org.za/policy-document/209/.

Franchuck, J.E. (2004). Phenomenology vs grounded theory: The appropriate approach to use to study the perspectives of instructional librarians on their roles in information literacy education for undergraduates. Paper written for Interdisciplinary Studies 560, Qualitative Methods. Retrieved from http://www. slis.ualberta.ca/cap04/judy/paper.htm.

Graneheim, U.H., \& Lundman, B. (2004). Qualitative content analysis in nursing research: Concepts, procedures and measures to achieve trustworthiness. Nurse Education Today, 24(5), 105-112. https://doi.org/10.1016/j.nedt.2003. 10.001

Hanton, S., Fletcher, D., \& Coughlan, G. (2005). Stress in elite sport performers: A comparative study of competitive and organizational stressors. Journal of Sports Sciences, 23(10), 1129-1141. https://doi.org/10.1080/02640410500131480

Health Professions Council of South Africa. (2013). Form 258: Framework for education, training, registration and scope of registered counsellors. Retrieved
from www.hpcsa.co.za/Uploads/editor/UserFiles/downloads/psych/psycho_ policy/form_258_registered_counsellor_\%2004oct_2013.pdf.

Jobes, P.C. (2003). Human ecology and rural policing: A grounded theoretical analysis of how personal constraints and community characteristics influence strategies of how personal constraints and community characteristics influence strategies
of law enforcement in rural new South Wales, Australia. Police Practice and of law enforcement in rural new South Wales, Australia. Police Practic
Research, 4(1), 3-19. https://doi.org/10.1080/1561426032000059150

Kgalema, L. (2002). Victim awareness and trauma management in metropolitan police services. Research report. Centre for the Study of Violence and Reconciliation. Retrieved from http://www.wits.ac.za/csvr/papers/papkgal2.htm.

Klaic, A., Burtscher, M.J., \& Jonas, K. (2018). Person-supervisor fit, needs-supplies fit, and team fit as mediators of the relationship between dual-focused transformational leadership and well-being in scientific teams. European Journal of Work and Organisational Psychology, 27(5), 669-682. https://doi.org/10.1080 of Work and Organisation
/1359432X.2018.1502174

Kohan, A. \& Mazmanian, D. (2003). Police work, burnout and pro-organizational behavior: A consideration of daily work experiences. Criminal Justice and Behavior, 30(5), 559-583. https://doi.org/10.1177/0093854803254432

Lim, H., \& Kim, J.L. (2015). Organizational stressors associated with six aspects of police officer stress in South Korea. Health Science Journal, 10(1), 1-12.

Louw, G.J., \& Viviers, A. (2010). An evaluation of a psychosocial stress and coping model in the police work context. South African Journal of Industrial Psychology, 36(1). https://doi.org/10.4102/sajip.v35i1.442.

Ludick, M., Alexander, D., \& Carmichael, T. (2007). Vicarious traumatisation: Secondary traumatic stress levels in claims workers in the short-term insurance industry in South Africa. Problems and Perspectives in Management, 5(3), 99-110.

Madu, S.N., \& Poodhun, S.E.A. (2006). Stress symptoms and substance use among police officials in the central region of Limpopo Province, South Africa. Journa of Social Science, 12(3), 213-224. https://doi.org/10.1080/09718923.2006.1197 8394

Maguen, S., Metzler, T.J., McCaslin, S.E., Inslicht, S.S., Henn-Haase, C., Neylan, T.C., \& Marmar, C.R. (2009). Routine work environment stress and PTSD symptoms in police officers. The Journal of Nervous and Mental Disease, 197(10), 754-760. https://doi.org/10.1097/NMD.0b013e3181b975f8

Meyer, J.P., Gagne, M., \& Parfyonova, N.M. (2010). Toward an evidence-based model of engagement: What we can learn from motivation and commitment research. In S. L. Albrecht (Ed.), New horizons in management. Handbook of employee engagement: Perspectives, issues, research and practice (pp. 62-73). Northampton: Edward Elgar Publishing.

Meyer, R., Rothmann, S., \& Pienaar, J. (2003). Coping, stress and suicide ideation in the South African Police Service in the Eastern Cape. South African Journal of Economic Management Sciences, 6(4), 881-904. https://doi.org/10.4102/sajems. v6i4.1527

Mostert, K., Cronje, S., \& Pienaar, J. (2006). Job resources, work engagement and the mediating role of positive work-home interaction of police officers in the North West province. Acta Criminologica, 19(3), 64-87.

Morash, M., Haarr, R., \& Kwak, D. (2006). Multilevel influences on police stress. Journal of Contemporary Criminal Justice, 22(1), 26-43. https://doi. org/10.1177/1043986205285055

Nemasisi, R.R. (2018). Contributory factors leading to domestic violence: A case study of Manganya village in Thulamela local municipality. Unpublished master's thesis. Thohoyandou: University of Venda. 
Nzewi, O. (2013). Organisational work procedures and service efficiency: Conceptual extrapolations and views from an organisational policy and procedures review process. Journal of Public Administration, 48(1), 5-20.

Patterson, G.T. (2001a). Reconceptualising traumatic incidents experienced by law enforcement personnel [Electronic version]. The Australasian Journal of Disaster and Trauma Studies, 5(2).

Patterson, G.T. (2001b). The relationship between demographic variables and exposure to traumatic incidents among police officers [Electronic version]. The Australasian Journal of Disaster and Trauma Studies, 2.

Pearlman, L.A., \& Saakvitne, K.W. (1995). Treating therapists with vicarious traumatization and secondary traumatic stress disorder. In C. R. Figley (Ed.), Compassion fatigue: Coping with secondary traumatic stress disorder in those who treat the traumatised (pp. 150-177). Bristol: Brunner/Mazel Publishers.

Pienaar, J., \& Rothmann, S. (2003). Coping strategies in the South African Police Service. Journal of Industrial Psychology, 29(4), 81-90. https://doi.org/10.4102/ sajip.v29i4.123

Pienaar, J., \& Rothmann, S. (2006). Occupational stress in the South African Police Service. South African Journal of Industrial Psychology, 32(3), 72-78. https://doi. org/10.4102/sajip.v32i3.439

Pietkiewicz, I., \& Smith, J.A. (2014). A practical guide to using interpretative phenomenological analysis in qualitative research psychology. Psychological Journal, 20(1), 7-14. https://doi.org/10.14691/CPPJ.20.1.7

Redelinghuys, K., Rothmann, S., \& Botha, E. (2019). Workplace flourishing Measurement, antecedents and outcomes. South African Journal of Industrial Psychology, 45(0), n.p. https://doi.org/10.4102/sajip.v45i0.1549

Rees, B., \& Smith, J.S. (2008). Breaking the silence: The traumatic circle of policing. International Journal of Police Science and Management, 10(3), 267-279. https:// doi.org/10.1350/ijps.2008.10.3.83

Sabin-Farrell, R., \& Turpin, G. (2003). Vicarious traumatisation: Implications for the mental health of health workers. Clinical Psychology Review, 23(3), 449-480. https://doi.org/10.1016/S0272-7358(03)00030-8

Salston, M., \& Figley, C.R. (2003). Secondary traumatic stress effects of working with survivors of criminal victimization. Journal of Traumatic Stress, 16(2), 167-174. https://doi.org/10.1023/A:1022899207206

Shane, J.M. (2010). Organizational stressors and police performance. Journal of Criminal Justice, 38, 807-818. https://doi.org/10.1016/j.jcrimjus.2010.05.008
Smith, R. (2010). Policing the changing landscape of rural crime: A case study from Scotland. International Journal of Police Science and Management, 12(3), 373-387. https://doi.org/10.1350/ijps.2010.12.3.171

South African Police Service Annual Report. (2010/11). SAPS together squeezing crime to zero. Retrieved from http://www.info.gov.za/view/Download FileAction?id=152417.

South African Police Service. (2013/2014). Annual report for 2013/2014 financial year-Vote 25: Department of Police. Retrieved January from https://pmg assets. s3-website-eu-west-1.amazonaws.com/141015SAPSar.pdf.

South African Police Service. (2017/2018). Annual report 2017/2018. Retrieved from https://www.gov.za/sites/default/files/gcis_document/201810/saps-annualreport.pdf.

South African Police Service. (2018/2019). Annual Performance Plan: 2018/2019. Retrieved from https://www.saps.gov.za/.../strategic_plan/2018.../annual_ performance_plan_2018_2019_updated.pdf.

South African Police Service. (2018). Crime situation in RSA twelve months 01 April 2017 to 31 March 2018. Retrieved from https://www.gov.za/sites/default/files/ gcis_document/201809/crime-stats201718.pdf.

South African Police Service Crime Statistics. (2012). Crime research and statistics. Retrieved from http://www.saps.gov.za/statistics/reports/crimestats/2012/ categories/total_sexual_offences.pdf.

Steyn, R. (2009). Types and frequency of trauma and posttraumatic stress disorder among rural police in South Africa. Acta Criminologica, 22(3), 139-148.

Storm, K., \& Rothmann, S. (2003, May). Burnout in the South African Police Service. Poster presented at the 11th European Congress of Work and Organisational Psychology, Lisbon.

Van Lelyveld, C.R. (2008). The experience of vicarious trauma by the police officers within the South African Police Service in the Limpopo province. Unpublished master's thesis. University of Limpopo, Polokwane.

Violanti, J.M., Charles, L.E., McCanlies, E., Hartley, T.A., Baugman, P., Andrew, M.E., ... Burchfiel, C.M. (2017). Police stressors and health: A state-of-the-art review. An International Journal of Police Strategies and Management, 40(4), 642-656.

Waters, J.A., \& Ussery, W. (2007). Police stress: History, contributing factors, symptoms and interventions, Policing: An International Journal of Police Strategies and Management, 30(2), 169-188. https://doi.org/10.1108/13639510710753199

Wiese, L., Rothmann, S., \& Storm, K. (2003). Coping, stress and burnout in the South African Police Service in Kwazulu-Natal. South African Journal of Industria Psychology, 29(4), 71-80. https://doi.org/10.4102/sajip.v29i4.124 